\title{
Virus-induced Airway Hyperresponsiveness in Guinea Pigs Is Related to a Deficiency in Nitric Oxide
}

\author{
Gert Folkerts, Henk J. van der Linde, and Frans P. Nijkamp \\ Department of Pharmacology, Utrecht Institute for Pharmaceutical Sciences, Utrecht University, 3508 TB Utrecht, The Netherlands
}

\begin{abstract}
Intratracheal inoculation of parainfluenza type 3 virus to guinea pigs induces a marked increase in airway responsiveness in vivo and in vitro. In spontaneously breathing anesthetized guinea pigs inhalation of an aerosol containing the nitric oxide (NO) precursor L-arginine $(2.0 \mathrm{mM})$ completely prevented the virus-induced airway hyperresponsiveness to histamine. In addition, perfusion of L-arginine $(200 \mu \mathrm{M})$ or the direct NO-donor $S$-nitroso- $N$-acetyl-penicillamine (SNAP, $1 \mu M$ ) through the lumen of tracheal tubes from infected animals prevented the increase in airway responsiveness to histamine or the cholinoceptor agonist methacholine. The NO synthase inhibitor $N^{\omega}$-nitro-Larginine methyl ester (L-NAME, $120 \mu M$ ) did not further increase the virus-induced airway hyperresponsiveness.

In additional experiments, NO was measured with an Iso-NO nitric oxide meter and sensor. Stimulation of control tissues in vitro with histamine $\left(10^{-3} \mathrm{M}\right)$ resulted in a contraction with a simultaneous release of $\mathrm{NO}(44.5 \pm 5.4 \mathrm{nM})$. The release of NO was markedly reduced by $75 \%$ ( $P$ $<0.01,11.4 \pm 3.1 \mathrm{nM}$ ) in tracheas from virus-infected animals that demonstrated enhanced contractile responses. Preincubation of tissues from virus-treated guinea pigs with L-arginine $(200 \mu \mathrm{M})$ completely prevented the enhanced contraction and simultaneously returned the NO production to control values $(51.2 \pm 3.4 \mathrm{nM})$.

An NO deficiency might be causally related to the development of airway hyperresponsiveness after a viral respiratory infection. (J. Clin. Invest. 1995. 95:26-30.) Key words: L-arginine $\bullet$ pulmonary resistance $\cdot$ perfused tracheal tube - parainfluenza 3 virus $\cdot$ epithelium-derived relaxing factor
\end{abstract}

\section{Introduction}

Airway hyperresponsiveness is observed in the majority of asthmatic patients. Respiratory infections induce airway hyperresponsiveness in healthy persons and cause exacerbations in asth-

Address correspondence to Dr. Gert Folkerts, Department of Pharmacology, Utrecht Institute for Pharmaceutical Sciences, Utrecht University, P.O. Box 80082, 3508 TB, The Netherlands. Phone: 30-534509/537353; FAX: 30-537420; e mail: G. FolkertsFar.RUU.NL.

Received for publication 7 February 1994 and in revised form 25 July 1994.

1. Abbreviations used in this paper: L-NAME, $N^{\omega}$-nitro-L-arginine methyl ester; NO, nitric oxide; PI-3, parainfluenza type 3 ; $\mathrm{R}_{\mathrm{L}}$, pulmonary resistance; SNAP, $S$-nitroso- $N$-acetyl-penicillamine.

J. Clin. Invest.

(c) The American Society for Clinical Investigation, Inc. 0021-9738/95/01/0026/05 \$2.00

Volume 95, January 1995, 26-30 matic patients (1-3). Recently, we showed that intratracheal inoculation of guinea pigs with parainfluenza type 3 (PI-3) ${ }^{1}$ virus induces an airway hyperresponsiveness in vivo and in vitro $(4,5)$. This hyperresponsiveness is present at $4 \mathrm{~d}$ after inoculation and remained at least up to day 16 . Light microscopic and ultrastructural examination of the central airways of virus-infected animals revealed stratification of the epithelial lining with pronounced loss of cilia and granule-depleted goblet cells (6).

Nitric oxide (NO) may be involved in modifying airway responses (7). NO is present in exhaled air of animals and humans $(8,9)$. In the respiratory tract, nerves, endothelial cells, vascular and airway smooth muscle cells, inflammatory cells, and the airway epithelium are sources of NO or $S$-nitrothiols $(10,11)$. These products increase the level of intracellular cGMP and induce relaxations of airway smooth muscle preparations of both human and animal species $(12,13)$. It was found that NO can reverse the methacholine-induced bronchoconstriction in guinea pigs (14) and, moreover, we recently demonstrated that NO synthesis inhibitors induce hyperresponsiveness of guinea pig airways to histamine in vitro and in vivo, which can be reversed by the NO precursor L-arginine (7). Epithelium removal induces a similar degree of tracheal hyperresponsiveness when compared with the action of NO synthesis inhibitors in intact tissues. Furthermore, NO synthesis inhibitors did not induce an additional increase in tracheal responsiveness in epithelium-denuded tissues. These findings suggest a role for the epithelial layer in NO production.

Since in virus-infected guinea pigs airway hyperresponsiveness was found in association with epithelial damage $(4,6)$, the NO precursor L-arginine was administered to infected animals and airway responsiveness was investigated in vivo and in vitro. In addition, the release of NO was measured in the perfusion fluid after stimulation of the tissues with histamine in the absence or presence of $\mathrm{L}$-arginine.

\section{Methods}

Intratracheal inoculation. Suspensions of virus $(1 \mathrm{ml}$; tissue culture infective dose $e_{50}=10^{8.9} / \mathrm{ml}$ ) were centrifuged at $100,000 \mathrm{~g}$ and resuspended in a $1 / 10$ reduced volume $(0.1 \mathrm{ml})$ of sterile pyrogen-free saline to minimize possible mechanical effects of the inoculation procedure. Growth medium was subjected to a similar procedure to serve as a control solution. The animals were anesthetized with ether and inoculated with control solution or PI-3 virus $(0.1 \mathrm{ml})$ intratracheally as described previously (4-6). Bovine PI-3 virus was kindly provided by Solvay Duphar (Weesp, The Netherlands).

Airway responsiveness in vivo. The guinea pigs were anesthetized with urethane $(2.0 \mathrm{~g} / \mathrm{kg}$ body wt, intraperitoneally $) 4 \mathrm{~d}$ after inoculation with control solution or PI-3 virus. The animals were allowed to breathe spontaneously. An anesthesia-induced fall in body temperature was avoided by placing the animals in a heated chamber which kept the body temperature at $37^{\circ} \mathrm{C}$. The animals were prepared for the measurement of pulmonary resistance $\left(R_{L}\right)$ as follows. Airflow and tidal volume were determined by cannulating and connecting the trachea with Fleisch flow head ( $\mathrm{nr}$ 000; Meijnhart, Bunnik, The Netherlands) to a pneumotacho- 
graph. A pressure transducer (model MP45-2; Validyne Engineering Corp., Northridge, CA) measured the transpulmonary pressure by determining pressure differences between the tracheal cannula and a cannula filled with saline inserted in the esophagus. $R_{L}$ was determined breath by breath with a respiratory analyzer as described previously (15). $R_{L}$ was yielded by dividing transpulmonary pressure by airflow at isovolume points (50\%).

A small polyethylene catheter (PE-50) was placed in the right jugular vein for intravenous administration of increasing doses of histamine $(0.4-2.0 \mu \mathrm{g} / 100 \mathrm{~g}$ body wt). After the first histamine dose-response curve, the animals recuperated for $20 \mathrm{~min}$. Thereafter, the animals inhaled 10 breaths of an aerosol containing distilled water or L-arginine $(2.0 \mathrm{mM})$. This procedure was repeated every $5 \mathrm{~min}$ for $30 \mathrm{~min}$ (total of 60 breaths). Accordingly, a second histamine dose-response curve was made.

Airway responsiveness in vitro. $4 \mathrm{~d}$ after inoculation, the guinea pigs $(400-500 \mathrm{~g})$ were killed with an overdose of pentobarbitone sodium (Nembutal ${ }^{\oplus}, 0.6 \mathrm{~g} / \mathrm{kg}$ body wt, intraperitoneally). Tracheas were dissected free of connective tissue and blood vessels and isolated and perfused in an organ bath according to a modified method of Pavlovic and colleagues (16). In short, two hooks were inserted through opposite sides of the tracheal wall with the smooth muscle between them. One hook was attached to a fixed point in the organ bath; the other hook was connected to an isometric transducer (Harvard Apparatus Ltd., Kent, UK). The tracheal tension was set at an optimal counter weight of $2 \mathrm{~g}$. The inside of the trachea was perfused $(2 \mathrm{ml} / \mathrm{min})$ independently from the outside with Krebs solution of the following composition ( $\mathrm{mM}$ / liter): $\mathrm{NaCl}, 118.1 ; \mathrm{KCl}, 4.7 ; \mathrm{CaCl}_{2}, 2.5 ; \mathrm{MgSO}_{4}, 1.2 ; \mathrm{NaHCO}_{3}, 25.0$; $\mathrm{KH}_{2} \mathrm{PO}_{4}, 1.2$; and glucose, 8.3 , which was continuously gassed with a $5 \% \mathrm{CO}_{2}$ and $95 \% \mathrm{O}_{2}$ gas mixture as described before (7). Every 15 min the Krebs buffer was refreshed on both sides until a stable tone was reached (usually within $90 \mathrm{~min}$ ). The serosal side was not perfused. The intraluminal side of the trachea was perfused for 30 min with Krebs buffer containing $20 \mu$ l solvent solution (Krebs buffer), L-arginine (200 $\mu \mathrm{M})$, D-arginine $(200 \mu \mathrm{M})$, the NO synthesis inhibitor $N^{\omega}$-nitro-Larginine methyl ester (L-NAME, $120 \mu \mathrm{M}$; Sigma Chemical Company, St. Louis, MO), or the direct NO-donor $S$-nitroso- $N$-acetyl-penicillamine (SNAP, $1 \mu \mathrm{M}$; gift from Wellcome Industries, Beckenham, UK). Accordingly, isometric tension changes were measured after histamine (Onderlinge Pharmaceutische Groothandel, Utrecht, The Netherlands) or methacholine (Janssen Chemica, Geel, Belgium) concentration-response curves were made. Only one concentration-response curve was made on a tissue segment.

NO measurements. Airway responsiveness and NO release were measured simultaneously in tissues from control and PI-3 virus-infected animals. Preparations were stimulated intraluminally with histamine $\left(10^{-3} \mathrm{M}\right)$ in the absence and presence of $200 \mu \mathrm{M} \mathrm{L}$-arginine $(200 \mu \mathrm{M})$. NO was measured with an Iso-NO nitric oxide meter and sensor (World Precision Instruments, Mauer, Germany). Accurate and stable NO measurements were taken over a range of NO concentrations from $1 \mathrm{nM}$ $(0.03 \mathrm{ppb})$ to $20 \mu \mathrm{M}(600 \mathrm{ppb})$ in solutions with a volume of $>200$ $\mu \mathrm{l}$. The sensor probe housing was covered with a polymer membrane through which the NO diffuses. The electrode was filled with an electrolyte fluid for NO.

With a T-adaptor, the sensor probe was placed in the perfusion fluid. The perfusion fluid reached the sensor probe at $<3$-s distance from the trachea. Calibrations were made in aerated Krebs solution at $37^{\circ} \mathrm{C}$ which contained $0.1 \mathrm{M} \mathrm{H}_{2} \mathrm{SO}_{4}, 0.1 \mathrm{M} \mathrm{KI}$, and $0.14 \mathrm{M} \mathrm{K}_{2} \mathrm{SO}_{4}$. For calibrations, titrations with $\mathrm{KNO}_{2}$ were made according to the manufacturer's instructions.

Statistical analysis. Changes in the increase in $R_{L}$ between groups after construction of dose-response curves with histamine were tested using two-way ANOVA. The changes induced by individual doses of histamine were tested with Student's unpaired $t$ test. Differences between groups after cumulative concentration-response curves with histamine or methacholine on isolated tissues were tested with two-way ANOVA. Differences between groups with respect to the maximal contraction (in gram tension) and the amount of NO released (in nanomo-

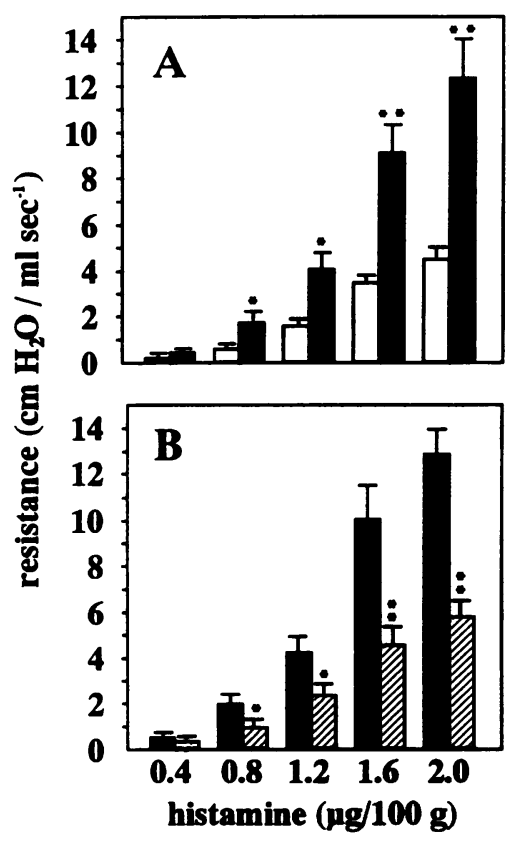

Figure 1. Changes in pulmonary resistance to intravenously administered histamine in guinea pigs $4 \mathrm{~d}$ after inoculation with $(A)$ control solution (open bars, $n=5$ ) or PI-3 virus (black bars, $n=5)$ and $(B)$ virustreated animals after an aerosol of distilled water (black bars) or L-arginine $(2.0 \mathrm{mM}$, hatched bars). Lung resistance is expressed as the actual minus the basal value (mean $\pm \mathrm{SEM}) . \quad * P<$ 0.05 and $* * P<0.01$ Student's unpaired $t$ test: (A) the broncho-constriction in animals inoculated with virus is significantly larger than in those inoculated with control solution, and $(B)$ the broncho-constriction in animals treated with virus and exposed to an L-arginine aerosol is significantly diminished as compared with the virus-treated guinea pigs exposed to distilled water.

lars) were evaluated with Student's $t$ test (unpaired). All $P$ values $<0.05$ were considered to reflect a statistically significant difference.

\section{Results}

Airway responsiveness in vivo. The basal lung resistance value in the virus-treated animals was slightly higher $(0.27 \pm 0.02 \mathrm{~cm}$ $\left.\mathrm{H}_{2} \mathrm{O} / \mathrm{ml} \cdot \mathrm{s}^{-1}\right)$ than in the control guinea pigs $(0.20 \pm 0.01 \mathrm{~cm}$ $\mathrm{H}_{2} \mathrm{O} / \mathrm{ml} \cdot \mathrm{s}^{-1}$ ). Treatment of animals with control solution or $\mathrm{L}-$ arginine had no effect on these values. The histamine-induced increase in lung resistance was significantly enhanced by $200 \%$ $4 \mathrm{~d}$ after virus treatment (Fig. 1 A, black bars, ${ }^{*} P<0.05,{ }^{*} P$ $<0.01$ ) compared with controls (open bars). Exposure of an aerosol of solvent solution had no effect on the airway hyperresponsiveness in infected animals (Fig. $1 \mathrm{~B}$, black bars). An aerosol of the solvent solution to control animals also did not influence the airway responsiveness (data not shown). In contrast, when virus-treated guinea pigs were exposed to an aerosol of $\mathrm{L}$-arginine, the increase in lung resistance induced by histamine was completely reduced to control levels (Fig. $1 B$, hatched bars, $* P<0.05, * * P<0.01$ compared with virustreated guinea pigs exposed to distilled water [black bars]). Administration of L-arginine to control animals did not influence the airway responsiveness to histamine (data not shown), indicating that the effect of L-arginine is probably not caused by functional antagonism.

Airway responsiveness in vitro. Increasing concentrations of histamine perfused through the lumen of the trachea resulted in a concentration-dependent contraction of the tracheal smooth muscle. However, at a relatively high concentration of histamine $\left(10^{-3} \mathrm{M}\right)$, the contraction was small and the concentrationresponse curve did not reach a plateau (Fig. 2 A, open circles).

The histamine concentration-response curve was significantly $(P<0.01$, two-way ANOVA) shifted upwards after the viral respiratory infections. The maximal tracheal contraction 

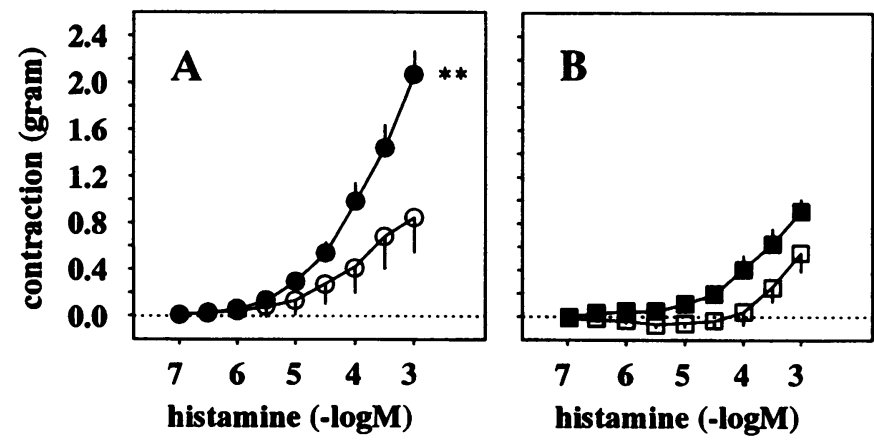

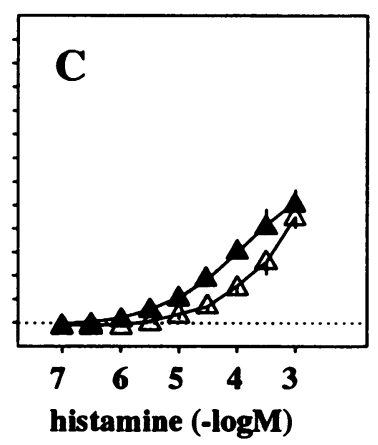

Figure 2. Effect of L-arginine (200 $\mu \mathrm{M})$ and SNAP $(1 \mu \mathrm{M})$ incubation on the histamine concentration-response curve made on isolated perfused tracheal tubes obtained from control and virus-infected guinea pigs. $(A)$ The histamine concentration-response curve was significantly shifted upwards after virus inoculation (closed circles, $n=5$ ) compared with the controls (open circles, $n=$ 5). ${ }^{* *} P<0.01$, two-way ANOVA $(B)$ L-Arginine incubation slightly shifted the histamine concentration-

response curve of the control tissues to the right without a significant effect on the maximal response (open squares, $n=6$ ). L-Arginine suppressed the enhanced tracheal contraction in the virus-treated group (closed squares, $n=5)$. (C) SNAP incubation also slightly shifted the concentrationresponse curve of the control preparations to the right without an effect on the maximal response (open triangles, $n=5$ ). The virus-induced airway hyperresponsiveness was suppressed by SNAP incubation (closed triangles, $n=5$ ). Each data point is the mean \pm SEM.

in the virus-treated group was increased by $135 \%$ compared with the controls (Fig. $2 A$, closed circles, $P<0.01$ ). Incubation of L-NAME $(120 \mu \mathrm{M})$ did not influence the virus-induced airway hyperresponsiveness; the maximal response $(2.03 \pm 0.23$ $\mathrm{g}, n=5$ ) was increased by $140 \%$ compared with the controls.

L-Arginine $(200 \mu \mathrm{M})$ or SNAP $(1 \mu \mathrm{M})$ incubation had no effect on the basal tone of the tissues of both groups. L-Arginine or SNAP incubation did not significantly influence the maximal contractions of the control tissues and slightly shifted the histamine concentration-response curves to the right (Fig. 2, $B$ and $C$, open squares and open triangles, respectively). In contrast, L-arginine, but not D-arginine $(200 \mu \mathrm{M})$, and SNAP prevented the virus-induced airway hyperresponsiveness (Fig. 2, $B$ and $C$, closed squares and triangles, respectively).

The methacholine concentration-response curve was significantly $(P<0.01$, two-way ANOVA) enhanced in tracheas obtained from virus-infected animals. The maximal contraction of the control group was $1.50 \pm 0.15 \mathrm{~g}(n=6)$ and was increased to $2.59 \pm 0.22 \mathrm{~g}$ in the virus group $(P<0.01, n=6)$. L-Arginine did not influence the responses in the control group (maximal contraction $1.35 \pm 0.14 \mathrm{~g} ; n=5$ ). The maximal response of $\mathrm{L}$ arginine-pretreated tracheas of the virus group $(1.76 \pm 0.13 \mathrm{~g}$, $n=5$ ) did not differ from the control groups with or without L-arginine, but was significantly suppressed $(P<0.02)$ compared with the virus group.

NO measurements. The basal NO production by the tissues was below the detection limit of the NO electrode $(<1 \mathrm{nM})$. Pilot studies revealed that accurate NO measurements could only be obtained after stimulation of the tissues with one concentration of histamine instead of performing a cumulative concentration-response curve, probably due to the slower release of NO. The contraction induced by $10^{-3} \mathrm{M}$ histamine, in the absence or presence of $\mathrm{L}$-arginine, of tissues obtained from control and virus-infected animals was similar to that observed after cumulative concentration-response curves with histamine (Fig. $3 \mathrm{~A}$ ). The histamine-induced contraction of the control tissues was associated with a simultaneous release of NO in the perfusion fluid (Fig. 3 B, open bars; Fig. 4, $A$ and $B$ ). Preincubation of the tissues with L-arginine did not further enhance the NO release (Fig. 3 B, stippled bars). Interestingly, the histamine-induced airway hyperresponsiveness in the virustreated group was associated with a $75 \%$ decrease in the release of NO (Fig. $3 B$, black bars; Fig. $4, A$ and $B, P<0.01$ ). Both the airway hyperresponsiveness and the decrease in the NO release could be prevented by the preincubation of the tissues with L-arginine (Fig. 3, $A$ and $B$, hatched bars).

\section{Discussion}

From this study it is concluded that the virus-induced airway hyperresponsiveness may be caused by a deficiency in NO. L-Arginine nonspecifically prevented the virus-induced airway hyperresponsiveness to both histamine and methacholine. Interestingly, the simultaneous decrease in the NO concentration during the increased airway contraction was also counteracted by L-arginine. The NO synthesis inhibitor L-NAME did not further enhance the tracheal contractility of virus-treated animals. These findings support the suggestion that the virus-induced airway hyperresponsiveness is mediated by NO. L-Arginine incubation of control tissues did not suppress the airway

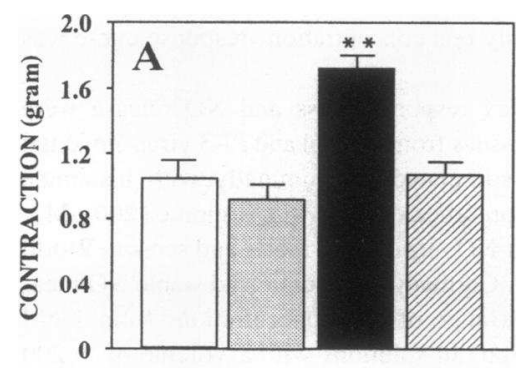

Figure 3. Histamine $\left(10^{-3} \mathrm{M}\right)$-induced contraction and NO release, in the absence and presence of $L$-arginine $(200$ $\mu \mathrm{M})$, of perfused isolated tracheal tubes obtained from control and virus-infected guinea pigs. In control tissues the histamine-induced

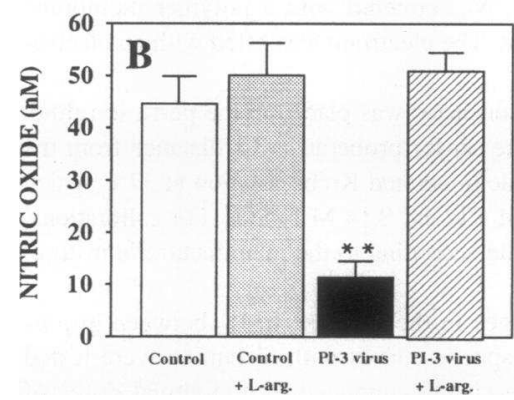
contraction was associated with a simultaneous release of NO (open bars, $A$ and $B, n=4)$. LArginine incubation had no effect on the contraction or NO release (stippled bars, $A$ and $B, n=$ 4). The histamine-induced contraction in the virus-infected group was significantly enhanced

(black bar, $A, * * P<0.01$, Student's unpaired $t$ test, $n=5$ ) and was associated with a significant decrease in NO production (black bar, $B$, $* * P<0.01$, Student's unpaired $t$ test, $n=5$ ). Incubation of $\mathrm{L}$-arginine completely prevented the enhanced contraction and the decreased NO production (hatched bars, $A$ and $B, n=5$ ). 


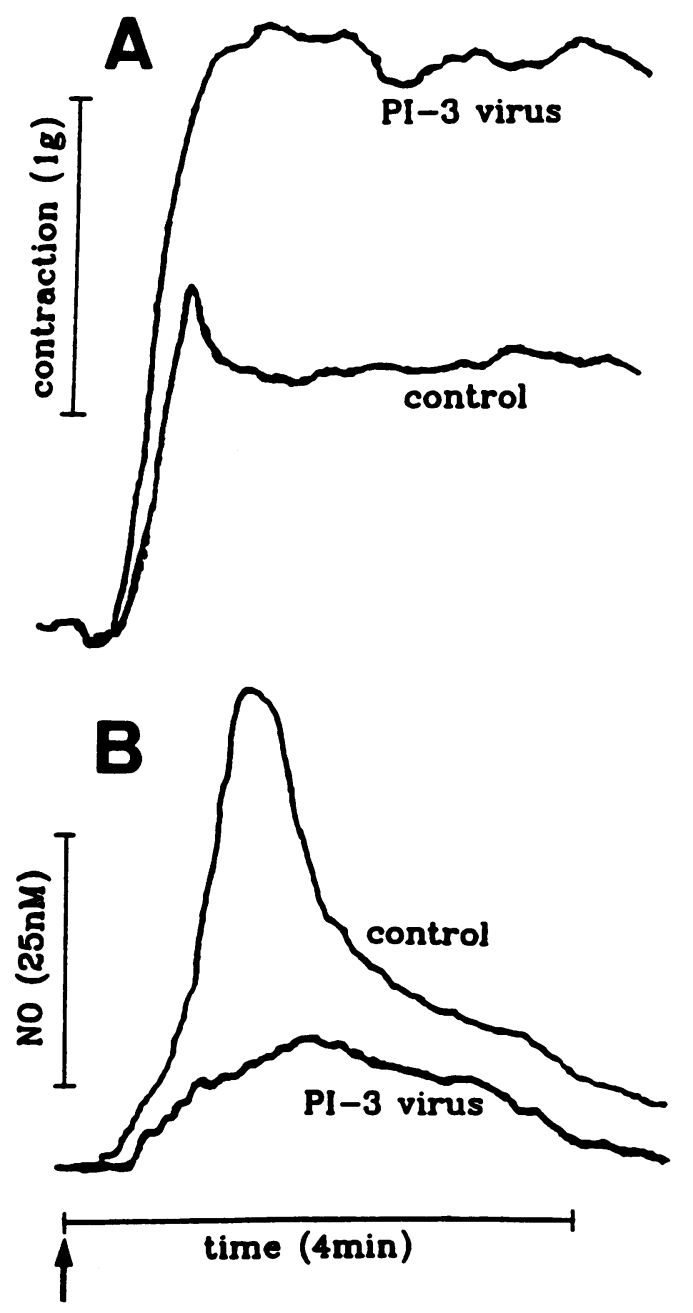

Figure 4. Individual tracings of the histamine $\left(10^{-3} \mathrm{M}\right)$-induced contraction $(A)$ and NO release $(B)$ of perfused isolated tracheal tubes obtained from control and virus-infected guinea pigs. In a preparation obtained from a virus-infected animal, the histamine-induced contraction was enhanced and NO production was markedly suppressed compared with the control tissue. Arrow indicates addition of histamine.

responsiveness or enhance the NO production. Therefore, it is likely that under basal conditions the activity of the enzyme NO synthase is already maximal and that sufficient precursor and co-factors are present.

Among others, three possible mechanisms may account for the NO deficiency in virally infected airways. First, the decreased NO production can be explained by substrate limitation, e.g., a decreased concentration of L-arginine in virus-treated animals. However, intracellular levels of arginine are already high and the supply of arginine is normally not rate-limiting for the constitutive enzyme (17). On the other hand, we cannot exclude the possibility that the activity of arginase, the enzyme that breaks down arginine, is increased. Arginase is widely distributed in the body including the lungs (18) and is elevated during growth of tissues and tumors (19). Whether the arginase activity is increased in the lungs during viral respiratory infections needs to be investigated.

Second, the epithelial layer is damaged in virus-infected animals $(4,6)$. Recently, we demonstrated that the epithelial layer might be a source for NO since epithelium removal and incubation of intact tracheal tubes with NO synthesis inhibitors both induced a similar degree of airway hyperresponsiveness. Moreover, incubation of epithelium-denuded tissues with NO synthesis inhibitors did not induce an additional increase in airway responsiveness. In agreement, herewith it was found that cultured bovine airway epithelial cells metabolize L-arginine to L-citrulline, an effect blocked by NO synthesis inhibitors, indicating that airway epithelial cells have the capacity to produce NO (20). A cultured human epithelial cell line produces nitrite spontaneously, which can be suppressed by a NO synthesis inhibitor and restored by L-arginine, suggesting the constitutive production of NO (21). A number of contractile agents stimulate the constitutive NO synthase $(10,11)$. Therefore, a likely explanation for the lack in NO in virus-treated animals is a diminished activity or availability of the constitutive NO synthase which might be due to epithelial damage. The constitutive NO synthase is present in rat airway epithelial cells but not in human airway epithelium (22). A cause of this discrepancy might be that the specimens of the human airways were taken from diseased lungs versus the healthy airways of the rat. Indeed, in biopsies of human airways, immunoreactivity to inducible NO synthase was seen in the epithelium in 22 out of 23 asthmatic cases, but only 2 out of 14 nonasthmatic controls (23). Although in diseased airways the inducible NO synthase is present and under basal conditions the NO concentration in exhaled air is higher in asthmatic patients (24), it cannot be excluded that the NO released by the activity of the constitutive is diminished during bronchoconstriction. Indeed, in healthy humans NO concentrations in exhaled air are increased after breath holding or exercise (9). Further, inhalation of NO diminishes the airways contractions induced by cholinergic agonists in guinea pigs, rabbits, and humans $(14,25,26)$.

A third mechanism by which the concentration of NO can be decreased is the following. NO is inactivated by products released from inflammatory cells, i.e., superoxide anions (10, 11). PI-3 virus activates inflammatory cells (5), and the number of inflammatory cells is increased in lungs of virus-infected guinea pigs $(5,27)$. Naive guinea pig tracheas incubated with inflammatory cells obtained from lungs of virus-treated animals become hyperresponsive to histamine (28). Besides decreasing the NO concentration, the reactive peroxynitrite $\left(\mathrm{ONOO}^{-}\right)$is produced by the interaction of superoxide anions with NO (10, 11 ), which accordingly may lead to additional epithelial damage. Moreover, isolated guinea pig epithelial cells themselves can release reactive oxygen species (29).

Epidemiological studies have demonstrated a close temporal association between respiratory viral infections and exacerbations of asthma. In addition, in otherwise healthy people, respiratory infections induce airway hyperresponsiveness. Viruses have been identified in up to $50 \%$ of wheezing illnesses and asthma exacerbations occurring in childhood and up to $20 \%$ of those in adults. Moreover, viral infections have been shown to develop into late asthmatic reactions (1-3). A deficiency in NO, due to a decreased substrate concentration, a decreased activity or availability of the constitutive enzyme, or to the inactivation by mediators from inflammatory cells, may contribute to the above mentioned phenomena. Epithelial damage, airway inflammation, and an enhanced release of reactive oxygen species by inflammatory cells are observed both during viral respiratory infections and asthma (30-33).

Besides NO, other mechanisms may also contribute to the development of airway hyperresponsiveness. Airway contractions in response to substance $P$ and capsaicin are increased in 
PI-3 virus-infected guinea pigs (34). Further, as shown by Jacoby et al. (35), the enzymatic activity of enkephalinase is decreased and the reactivity to substance $P$ is increased in ferret airways tissues incubated with influenza virus for $4 \mathrm{~d}$. Further, we showed that the anti-tussive drug levodropropizine could prevent the development of the virus-induced airway hyperresponsiveness (36). In addition, histamine may play a role in the virus-induced airway hyperresponsiveness. In patients infected with respiratory syncytial virus, the release of histamine in nasopharyngeal secretions was detected significantly more often and in higher concentrations in patients with wheezing (37). Histamine concentrations are increased in the broncho-alveolar lavage fluid of PI-3 virus-treated guinea pigs (6) and antiallergic drugs and antihistamines can prevent the virus-induced airway hyperresponsiveness and influx of inflammatory cells (27). Therefore, a number of processes may act additively or synergistically during the development of airway hyperresponsiveness.

This is the first report which shows that airway hyperresponsiveness is associated with a deficiency of NO. The airway hyperresponsiveness could be prevented not only by L-arginine but also by the direct NO-donor SNAP. These results highlight the possibility that these agents could herald a new era of bronchodilator drugs.

\section{Acknowledgment}

The authors would like to thank Dr. T. L. Buckley for correction of the English language.

\section{References}

1. Busse, W. W. 1991. Viral infections and allergic disease. Clin. Exp. Allergy. $21: 68-71$

2. Pattemore, P. K., S. L. Johnston, and P. G. Bardin. 1992. Viruses as precipitants of asthma symptoms. Clin. Exp. Allergy. 22:325-336.

3. Bardin, P. G., S. L. Johnston, and P. K. Pattemore. 1992. Viruses as precipitants of asthma symptoms. II. Physiology and mechanisms. Clin. Exp. Allergy. 22:809-822.

4. Folkerts, G., A. Verheyen, and F. P. Nijkamp. 1992. Viral infection in guinea pigs induces a sustained non-specific airway hyperresponsiveness and morphological changes of the respiratory tract. Eur. J. Pharmacol. Environ. Toxicol. Pharmacol. 228:121-130.

5. Folkerts, G., B. van Esch, M. Janssen, and F. P. Nijkamp. 1992. Virusinduced airway hyperresponsiveness in guinea pigs in vivo: study of bronchoalveolar cell number and activity. Eur. J. Pharmacol. Environ. Toxicol. Pharmacol. 228:219-227.

6. Folkerts, G., A. K. C. P. Verheyen, G. M. A. Geuens, H. F. Folkerts, and F. P. Nijkamp. 1993. Virus-induced changes in airway responsiveness, morphology, and histamine levels in guinea pigs. Am. Rev. Respir. Dis. 147:1569-1577.

7. Nijkamp, F. P., H. J. Van der Linde, and G. Folkerts. 1993. Nitric oxide synthesis inhibitors induce airway hyperresponsiveness in the guinea pig in vivo and in vitro. Am. Rev. Respir. Dis. 148:727-734.

8. Gustafsson, L. E., A. M. Leone, M. G. Persson, N. P. Wiklund, and S. Moncade. 1991. Endogenous nitric oxide is present in the exhaled air of rabbits, guinea pigs and humans. Biochem. Biophys. Res. Commun. 181:852-857.

9. Persson, M. G., N. P. Wiklund, and L. E. Gustafsson. 1993. Endogenous nitric oxide in single exhalations and the change during exercise. Am. Rev. Respir. Dis. 148:1210-1214.

10. Barnes, P. J., and M. G. Belvisi. 1993. Nitric oxide and lung disease. Thorax. 48:1034-1043.

11. Nijkamp, F. P., and G. Folkerts. 1994. Nitric oxide and bronchial reactivity. Clin. Exp. Allergy. 24:905-914.

12. Jansen, A., J. Drazen, J. A. Osborne, R. Brown, J. Loscalzo, and J. S. Stamler. 1992. The relaxant properties in guinea pig airways of $S$-nitrothiols. $J$. Pharmacol. Exp. Ther. 261:154-160.

13. Gaston, B., J. M. Drazen, A. Jansen, D. A. Sugarbaker, J. Loscalzo, and
J. S. Stamler. 1992. Relaxation of human airways in vitro by $S$-nitrosothiols. Am. Rev. Respir. Dis. 145:A384. (Abstr.)

14. Dupuy, P. M., S. A. Shore, J. M. Drazen, C. Frostell, W. A. Hill, and W. M. Zapol. 1992. Bronchodilator action of inhaled nitric oxide in guinea pigs. J. Clin. Invest. 90:421-428.

15. Folkerts, G., P. A. J. Henricks, P. J. Slootweg, and F. P. Nijkamp. 1988. Endotoxin-induced inflammation and injury of the guinea pig respiratory airways cause bronchial hyporeactivity. Am. Rev. Respir. Dis. 137:1441-1448.

16. Pavlovic, D., M. Fournier, M. Aubier, and R. Pariente. 1989. Epithelial vs. serosal stimulation of tracheal muscle: role of epithelium. J. Appl. Physiol. 67:2522-2526

17. McCall, T., and P. Vallance. 1992. Nitric oxide takes centre-stage with newly defined roles. Trends Pharmacol. Sci. 13:1-6.

18. Aminlari, M., and T. Vaseghi. 1992. Arginase distribution in tissues of domestic animals. Comp. Biochem. Physiol. 103B:385-389.

19. Taylor, A. A., and G. R. Stewart. 1981. Tissue and subcellular localization of enzymes of arginine metabolism in pisum sativum. Biochem. Biophys. Res. Commun. 101:1281-1289.

20. Robbins, R. A., F. G. Hamel, A. A. Floreani, G. L. Gossman, K. J. Nelson, S. Belenky, and I. Rubinstein. 1992. Bovine bronchial epithelial cells metabolize L-arginine to L-citrulline: possible role of nitric oxide synthase. Life Sci. 52:709_ 716.

21. Chee, C., B. Gaston, C. Gerard, J. Loscalzo, L. Kobzik, J. M. Drazen, and J. Stamler. 1993. Nitric oxide is produced by human epithelial cell line. Am. Rev. Respir. Dis. 147:A433. (Abstr.)

22. Kobzik, L., D. S. Bredt, C. J. Lowenstein, J. Drazen, B. Gaston, D. Sugarbaker, and J. S. Stamler. 1993. Nitric oxide synthase in human and rat lung: immunocytochemical and histochemical localization. Am. J. Respir. Cell Mol. Biol. 9:371-377.

23. Springall, D. R., O. A. Hamid, L. K. D. Buttery, P. Chanez, P. Howarth J. Bousquet, S. T. Holgate, and J. M. Polak. 1993. Nitric oxide synthase induction in airways of asthmatic subjects. Am. Rev. Respir. Dis. 147:A515. (Abstr.)

24. Kharitonov, S. A., D. Yates, R. A. Robbins, R. Logan-Sinclair, E. A. Shinebourne, and P. J. Barnes. 1994. Increased nitric oxide in exhaled air of asthmatic patients. Lancet. 343:133-135.

25. Högman, M., C. Frostell, H. Arnberg, and G. Hedenstierna. 1993. Inhalation of nitric oxide modulates methacholine-induced bronchoconstriction in the rabbit. Eur. Respir. J. 6:177-180.

26. Högman, M., C. G. Frostell, H. Hedenström, and G. Hedenstierna. 1993 Inhalation of nitric oxide modulates adult human bronchial tone. Am. Rev. Respir. Dis. 148:1474-1478.

27. Folkerts, G., F. De Clerck, I. Reijnart, P. Span, and F. P. Nijkamp. 1993. Virus-induced airway hyperresponsiveness in the guinea-pig: possible involvement of histamine and inflammatory cells. Br. J. Pharmacol. 108:1083-1093.

28. Folkerts, G., A. Verheyen, M. Janssen, and F. P. Nijkamp. 1992. Virusinduced airway hyperresponsiveness in the guinea pig can be transferred by bronchoalveolar cells. J. Allergy Clin. Immunol. 90:364-372.

29. Kinnula, V. L., K. B. Adler, N. J. Ackley, and J. D. Crapo. 1992. Release of reactive oxygen species by guinea pig tracheal epithelial cells in vitro. Am. J. Physiol. 262:L708-L712.

30. Laitinen, L. A., M. Heino, A. Laitinen, T. Kava, and T. Haahtela. 1985 Damage of the airway epithelium and bronchial reactivity in patients with asthma. Am. Rev. Respir. Dis. 131:599-606.

31. Djukanovic, R., W. R. Roche, J. W. Wilson, C. R. W. Beasley, O. P. Twentyman, P. H. Howarth, and S. T. Holgate. 1990. Mucosal inflammation in asthma. Am. Rev. Respir. Dis. 142:434-457.

32. Folkerts, G., and F. P. Nijkamp. 1993. Cells and mediators involved in airway hyperresponsiveness. In New Concepts in Asthma. J. P. Tarayre, B. Vergaftig, and E. Carilla, editors. Macmillan Publishers Ltd. London. 224-244.

33. Calhoun, W. J., H. E. Reed, D. R. Moest, and C. A. Stevens. 1992. Enhanced superoxide production by alveolar macrophages and air-space cells, airway inflammation, and alveolar macrophage density changes after segmental antigen bronchoprovocation in allergic subjects. Am. Rev. Respir. Dis. 145:317325.

34. Saban, R., E. C. Dick, R. I. Fishleder, and C. K. Buckner. 1987. Enhancement by parainfluenza 3 infection of the contractile response to substance $P$ and capsaicin in airway smooth muscle of the guinea pig. Am. Rev. Respir. Dis. 136:586-591.

35. Jacoby, D. B., J. Tamaoki, D. B. Borson, and J. A. Nadel. 1988. Influenza infection causes airway hyperresponsiveness by decreasing enkephalinase. $J$. Appl. Physiol. 64:2653-2658.

36. Folkerts, G., H. Van der Linde, C. Omini, and F. P. Nijkamp. 1993 Virus-induced airway inflammation and hyperresponsiveness in the guinea-pig is inhibited by levodropropizine. Naunyn-Schmiedebergs Arch. Pharmakol. 348:213-219.

37. Welliver, R. C., D. T. Wong, M. Sun, E. J. Middelton, R. S. Vaugan, and P. L. Orga. 1981. The development of respiratory syncytial virus-specific IgE and the release of histamine in nasopharyngeal secretions after infection. $N$. Engl. $J$. Med. 305:841-846. 